\title{
TEKNOLOGI PENGEMBANGAN DIGITAL DALAM MENGEMBANGKAN KOMPOSISI DAN ARANSEMEN PADA MUSIK MENGGUNAKAN SOFTWARE CUBASE
}

\author{
Yunanto Tri Laksono \\ Program Studi DIV Komputer Multimedia, Fakultas Teknologi dan Informatika, STIKOM Surabaya \\ Email: yunanto@stikom.edu
}

\begin{abstract}
Music is one component that plays an important role in one field of discipline that exists in the essence of life. One of the cultural products that developed in one time to the future, making music into one field of science parallel to other disciplines. Remembering this is marked by the large number of enthusiasts and the development of music from analog or manual music concepts evolved with the advent of the system's digital methodology. With the emergence of this development then the development is also marked with the development of supporting devices in developing the composition or arrangement. One of the tools that participates in developing competence is software. Software is a software used by the user in facilitating its use in any media either design or music. Cubase as one of emerge the tools in the form of software that is used to make music scoring or music dubbing, more flexible so it can facilitate in creating a new arrangement or composition.
\end{abstract}

Key Words: Music, Cubase Software, Composition and Arrangement

\begin{abstract}
Abstrak: Musik adalah salah satu komponen yang berperan penting dalam berkembanganya salah satu bidang disiplin ilmu yang ada dalam intisari kehidupan. Merupakan salah satu produk kebudayaan yang berkembang dalam satu masa ke masa, menjadikan musik menjadi salah satu bidang ilmu yang sejajar dengan disiplin ilmu yang lain. Memingat hal ini ditandai dengan banyaknya peminat dan berkembangnya musik dari konsep musik analog atau manual berkembang dengan munculnya metodologi digital sistem. Dengan munculnya perkembangan ini maka pengembangan ditandai pula dengan berkembangnya perangkat pendukung dalam mengembangkan komposisi ataupun aransemen. Salah satu perangkat yang turut serta mengembangkan kompetensi adalah software. Software merupakan perangkat lunak yang digunakan oleh usernya dalam mempermudah penggunaanya dalam media apapun baik desain ataupun musik. Cubase muncul sebagai salah satu perangkat berbentuk software yang digunakan untuk membuat music scoring ataupun music dubbing yang lebih fleksibel sehingga dapat mempermudah dalam menciptakan aransemen ataupun komposisi baru.
\end{abstract}

Kata kunci: Musik, Cubase Software, Komposisi dan Aransemen

\section{PENDAHULUAN}

Musik merupakan salah satu bagian dalam kearifan disiplin ilmu yang ada dalam masyarakat. Pola dan bentuk musik sendiri ditandai dengan munculnya berbagai aktifitas kebudayaan yang mengacu pada gerakan dan konsep suara baik dalam bentuk benda ataupun suara yang muncul dari intentitas manusia seperti bernyanyi.

Musik adalah penghayatan isi hati manusia yang diungkapkan dalam bentuk bunyi yang teratur dalam melodi atau ritme serta mempunyai unsur atau keselarasan pola imbal, pola berarti bentuk tetap, struktur, atau sistem, imbal berarti permainan bersahutsahutan antara bonang dan saron dalam karawitan jawa dan karawitan sunda (Panoe Banoe, 2003: 192).

Dari berkembangnya struktur dan pola kebudayaan yang ada dalam masyarakat, menjadikan identitas sebuah aransemen dan kompisisi menjadi berubah, hal ini dipicu tidak lain adalah karena adanya perkembangan teknologi yang sangat cepat, sehingga konsep manual yang pernah digunakan jadi berubah dengan masuknya pola digital.

Jamalus (1998: 1), mengatakan bahwa seni musik adalah suatu yang membuahkan hasil karya seni, berupa bunyi berbentuk lagu atau komposisi yang mengungkapkan fikiran serta perasaan penciptanya lewat unsur-unsur 
pokok musik, yakni irama, melodi, harmoni, serta bentuk atau susunan lagu dan ekspresi sebagai satu kesatuan. Dalam kaitannya dengan berbagai media dan bentuk, serta konsep penulisan dalam komposisi dan aransemen, menjadikan perubahan dalam media penulisan berbentuk teknologi digital.

Terdapat beberapa perangkat musik yang berbentuk yang digunakan dalam menuliskan partitur ataupun music scoring diantaranya adalah Cubase, Nuendo, Fruity Loops, Sibelius, Pro Tools dan juga masih banyak lagi media yang digunakan dalam menuliskan berbentuk music scoring. Software merupakan salah satu komponen penting dalam mengembangkan bentuk tulisan, serta memudahkan bagi para komposer dalam mengembangkan karya cipta dalam bentuk musik.

Melwin (2007) mengatakan bahwa perangkat lunak atau software itu sendiri merupakan sebuah perangkat yang berfungsi sebagai pengatur aktifitas kerja komputer dan semua interuksi yang mengarah kepada sebuah sistem komputer.

Lebih lanjut disebutkan pula bahwa sebuah perangkat lunak merupakan sebuah perangkat yang menjembatani interuksi user dengan komputer yang menggunakan bahan mesin.

Sistem operasional yang digunakan pun hampir sama dengan perangkat lain pada pengoperasian pada komputer sehingga lebih kompleks dan banyak fitur yang digunakan dalam penggunaanya. Software sendiri juga berkembang pada bidang dan ruang struktur lainnya yaitu pada bidang desain, bidang rupa dan bidang teknologi kesehatan. Karena pada bentuk prinsip dan modelnya, pengembangan pola dan bentuk penulisan mengacu pada era dan masa perkembangan di era jaman dulu, yang mengacu pada bentuk dan pola penulisan secara manual namun secara konsep penulisan masih mengacu pada beberapa pengembangan dalam bentuk manual yang dituliskan ke dalam bentuk digital.

\section{METODE}

Berdasarkan pada latar belakang permasalahan yang muncul dalam penelitian tentang media pembelajaran musik menggunakan software musik cubase dalam mengembangkan pola dan bentuk komposisi maupun aransemen, maka penelitian yang digunakan adalah peneltian berbentuk kualitatif.

Bogdan dan Taylor (dalam Sumaryanto, 2001: 2), mengatakan bahwa penelitian kualitatif adalah prosedur penelitian yang menghasilkan data deskriptif berupa kata-kata tertulis atau lisan dari orang-orang dan perilaku yang dapat diamati. Kirk dan Miller (dalam Sumaryanto, 2001: 2), mengatakan bahwa mendefinisikan penelitian kualitatif sebagai tradisi tertentu dalam penelitan sosial yang fundamental bergantung pada pengamatan pada manusia dalam kawasannya sendiri dan berhubungan dengan orang-orang tersebut dalam bahasannya dan dalam peristilahannya.

Pada penelitian ini lebih ditekannkan pada penelitian kualitatif yang digunakan untuk sampelnya adalah pada Institut Bisnis dan Informatika Stikom Surabaya, pada mata kuliah digital audio dan juga tata suara, dimana cubase digunakan sebagai alat dalam pembuatan musik maupun dalam memetakan konsep yang sangat sederhana, hal ini dikarenakan cubase sedikit mudah digunakan dalam membuat komposisi ataupun aransemen baru.

Dalam memperoleh data ataupun informasi penggunaan sumber data dan informasi yang berasal dari narasumber yang memiliki kompetensi dalam penggunaan cubase sehingga data yang diperoleh akan lebih valid, sehingga data yang diperlukan dan informasi akan lebih mendalam.

Dari beberapa data yang diperoleh kemudian di analisis maka dalam pengolahan data akan dikelompokkan sehingga bentuk observasi, wawancara, dokumentasi maupun studi literatur yang digunakan dapat menunjang pada proses penelitian sehingga hasil akhirnya dapat dikategorikan dan dianalisa berdasarkan kajian-kajian teori yang ada.

Nantinya diharapkan dari penyajian data yang dihasilkan dapat memberikan berbagai macam informasi yang dapat dijadikan sebagai kesimpulan. Sehingga nantinya data-data secara kualitatif mampu memetakan data yang diambil dalam bentuk pola-pola dan bagian dalam penggunaan cubase berdasarkan data yang sudah diperoleh dalam analisa penelitian. 


\section{HASIL DAN PEMBAHASAN}

Saat ini musik elektronik sudah sangat jauh lebih maju dan berkembang dan sangat dimudahkan dalam penggunaannya. Berbagai macam tambahan seperti Ableton, Bitwig, Steinberg, Logic (Hanya untuk mac pro) FL Studio dan beberapa program lainnya telah banyak digunakan dalam pembuatan musik elektronik. Sekarang sangat memungkinkan dalam memproduksi musik tanpa harus menggunakan atau dengan adanya musisi hanya. Dengan menggunakan laptonica, live coding dan algorave sudah dapat meunjuang dalam pembuatan komposisi. Sumber: www.stevesmith-production.com.

Dikutip juga dari Four Production, Brainvoyager Music, Herman von Helmmotz by David Cahan, Electronic Music by Elmert Herbert Die yang dituliskan oleh Nadya Amin pada tahun 2017, menambahkan bahwa kebanyakan software computer sekaligus sebagai sequencer musik, dengan sound card yang sudah di instalasi ke komputer, sequencer music bisa memainkan musik tanpa harus memerlukan midi eksternal untuk sound module.

Dikarenakan kebanayakan sequencer music dapat menggunakan software instrumen yang bisa memainkan MIDI message ke digital audio card. Instrumen software ini dapat mengubah pesan MIDI ke digital audio, meggunakan set piano, gitar, drum, string dalam bentuk gelombang kedalam RAM komputer. Hal ini mengacu bahwasannya music elektornic memiliki banyak variasi mulai dari bentuk alat, genre, tipe hingga ke dalam teknik bermain musik elektronik sehingga musik elektronik akan terus mengembangkan inovasinya seiring dengan perubahan dinamika jaman.

Cubase merupakan salah satu perangkat lunak dalam bentuk software musik, cubase sendiri mengalami perkembangan yang cukup cepat, mulai munculnya cubase seri 1 sampai cubase yang dibuat paling akhir yaitu tahun 2016, dan sampai hari ini cubase masih banyak digunakan oleh berbagai macam latar belakang disipin ilmu terutama yang berhubungan dengan musik.

$\mathrm{Hal}$ ini ditandai dengan makin banyaknya Music Producer muda yang coba menulis dan mengembangkan bentuk komposisi dan aransemen secara kebaruan, apalagi di era musik Electronic Dance Music (EDM) yang sangat familiar di masa sekitar tahun 2016, menjadikan paradigma dalam pengembangan media elektronik sebagai salah satu media yang sedang digemari terutama di kalangan muda yang mencintai musik.

Steinberg Cubase sendiri memiliki pengertian yaitu sebuah produk software musik yang dikembangkan oleh Jerman Software dan peralatan musik perusahaan Steinberg untuk merekam musik, mengatur dan mengedit sebagai bagian dari Digital Audio Workstation. Versi pertama, yang berlari pada Komputer Atari ST dan dicatat melalui MIDI saja, yang dirilis pada tahun 1989. Pada bulan januari 2003, Steinberg diakuisisi oleh perusahaan AS Pinnacle System, dimana ia beroperasi sebagai perusahaan independen sebelum dijual ke Yamaha Corporation di Desember 2004.

Dalam pelaksanaanya Cubase banyak dikembangkan oleh komposer yang muncul dari music production yang ada di Luar Negeri namun, saat ini banyak dari komposer lokal yang juga menggunkan dan mengembangan software ini. Sebernarnya dalam fungsi penggunaannya software ini sangat mudah namun yang menyusahkan adalah dalam processing data ataupun pada saat loading system program karena terkadang terkendala dari cara input program yang dimasukkan terkadang terdapat beberapa bagian data yang kurang pada saat memasukkan sehingga ketuntasan dalam proses data tidak lengkap, sehingga program tidak bisa dijalankan.

Cubase merupakan salah satu produk perangkat software dalam menulis dan menciptakan bentuk komposisi dengan berbasis media digital Cinematic. Dengan berbagai fitur tambahan dalam bentuk Vst dan Preset Sound memudahkan bagi para komposer dalam membuat ide dan konsep baru dalam menuliskan ide dan kreatifitasnya. Aransemen merupakan penyesuaian komposisi musik dengan nomor suara penyanyi atau instrumen lain didasarkan pada sebuah komposisi yang telah ada sehingga esensi musiknya tidak berubah.

Cubase telah ada di tiga inkarnasi utamaawalnya Cubase, yang menampilkan hanya MIDI, dan yang tersedia di Atari ST 
, Macintosh dan Windows. Setelah periode singkat dengan integrasi audio, versi berikutnya, Cubase VST, fitur lengkap rekaman audio terintegrasi dan pencampuran bersama dengan efek. (www.hogpictures.com).

\section{PENUTUP}

Berdasarkan pada kesimpulan dalam penelitian yang dilakukan dan dikembangan dengan kajian metodologi penulisan yang lebih valid maka, pengunaan software cubase dapat mengembangkan kreatifitas mahasiswa maupun praktisi yang berasal dari luar Institutsi untuk mengembangkan konsep penulisan musik dalam bentuk komposisi maupun aransemen, sehingga hasil yang diciptakan dalam penulisan komposisinya akan lebih menarik

Hasil ciptaan dan karya komposisi dalam menggunakan media digital dalam penggunaan software untuk pengembangan dalam membuat komposisi dan aransemen. Hasil nanti dapat dijadikan sebagai media referensi bagi para komposer dalam mengembangkan imaji karya dalam bentuk musik.

\section{DAFTAR PUSTAKA}

Banoe, Pono. (2003). Kamus Musik. Cetakan ke 1. Yogyakarta: PT. Kanisius.

Jamalus. 1998. Panduan Pengajaran Buku $\begin{array}{llr}\text { Pengajaran Musik } & \text { Melalui } \\ \text { Pengalaman } & \text { Musik. } & \text { Proyek }\end{array}$ Pengalaman Musik. Proyek Pengembangan Lembaga Pendidikan. Jakarta.

Daulay, Melwin Syahfrizal. 2007. Mengenal Hardware-Software dan Pengelolaan Instalasi Komputer. Yogyakarta: Andi

Kirk, J. \& Miller, M.L., 1986. Reliability and Validity In Qualitative Research, Beverly Hills, CA, Sage Publications.

Bogdan, Robert dan Taylor, Pengantar Metode Penelitian Kualitatif, Terjemahan Oleh Arief Rurchan, (Surabaya: Usaha Nasional, 1992).

www.stevesmith-production.com.

www.hog-pictures.com 